\title{
Promising Therapeutic Strategies for Mesenchymal Stem Cell-Based Cardiovascular Regeneration: From Cell Priming to Tissue Engineering
}

\author{
Seung Taek Ji, ${ }^{1}$ Hyunyun Kim, ${ }^{1}$ Jisoo Yun, ${ }^{1}$ Joo Seop Chung, ${ }^{2}$ and Sang-Mo Kwon ${ }^{1}$ \\ ${ }^{1}$ Laboratory for Vascular Medicine and Stem Cell Biology, Convergence Stem Cell Research Center, Medical Research Institute, \\ Pusan National University School of Medicine, Yangsan, Republic of Korea \\ ${ }^{2}$ Department of Internal Medicine, Medical Research Institute, Pusan National University School of Medicine, Busan, Republic of Korea
}

Correspondence should be addressed to Joo Seop Chung; hemon@pusan.ac.kr and Sang-Mo Kwon; smkwon323@hotmail.com

Received 15 September 2016; Revised 2 December 2016; Accepted 13 December 2016; Published 20 February 2017

Academic Editor: Elisabetta A. Cavalcanti-Adam

Copyright (C) 2017 Seung Taek Ji et al. This is an open access article distributed under the Creative Commons Attribution License, which permits unrestricted use, distribution, and reproduction in any medium, provided the original work is properly cited.

\begin{abstract}
The primary cause of death among chronic diseases worldwide is ischemic cardiovascular diseases, such as stroke and myocardial infarction. Recent evidence indicates that adult stem cell therapies involving cardiovascular regeneration represent promising strategies to treat cardiovascular diseases. Owing to their immunomodulatory properties and vascular repair capabilities, mesenchymal stem cells (MSCs) are strong candidate therapeutic stem cells for use in cardiovascular regeneration. However, major limitations must be overcome, including their very low survival rate in ischemic lesion. Various attempts have been made to improve the poor survival and longevity of engrafted MSCs. In order to develop novel therapeutic strategies, it is necessary to first identify stem cell modulators for intracellular signal triggering or niche activation. One promising therapeutic strategy is the priming of therapeutic MSCs with stem cell modulators before transplantation. Another is a tissue engineering-based therapeutic strategy involving a cell scaffold, a cell-protein-scaffold architecture made of biomaterials such as ECM or hydrogel, and cell patch- and 3D printing-based tissue engineering. This review focuses on the current clinical applications of MSCs for treating cardiovascular diseases and highlights several therapeutic strategies for promoting the therapeutic efficacy of MSCs in vitro or in vivo from cell priming to tissue engineering strategies, for use in cardiovascular regeneration.
\end{abstract}

\section{Introduction}

The World Health Organization (WHO) announced that the leading cause of death among chronic diseases worldwide is ischemic cardiovascular diseases, such as stroke and myocardial infarction (MI) [1]. Cardiovascular disease is caused by fat accumulation, platelet aggregation, and blood clots formation in the lining of blood vessels. Cardiovascular disease encompasses a very broad range of conditions, such as heart diseases, including MI, hypertension, heart failure, arrhythmias, cardiomyopathy, and ischemic heart disease due to atherosclerosis progression and vascular disease including peripheral vascular disease and stroke [2].

The treatment approach for the majority of cardiovascular disease is to administer drugs, and some cases may require surgery such as coronary angioplasty with stent insertion into the narrowed blood vessel to normalize blood flow through the coronary artery and coronary artery bypass [3]. In addition, gene therapy has been applied to treat cardiovascular disease [4]. In particular, phase II clinical trials of therapeutic angiogenesis using gene therapy are in progress, and the method is expected to be available soon for clinical use. The incidence of cardiovascular disease has continued to increase, and aside from transplantation, other therapies, despite recent advances in heart treatments, cannot fundamentally remedy the major etiology of cardiovascular disease; thus, there is a limit to how much treatment outcomes can be improved with the current approaches [5]. Although various studies have been conducted to overcome the limitations of cardiovascular therapies, stem cell therapy using several types of stem cells such as hematopoietic stem cells (HSCs), mesenchymal stem cells (MSCs), cardiac stem cells 
(CSCs), and endothelial progenitor cells (EPCs) provides an alternative approach, and remarkable advances have been made in clinical and basic research [6].

Several reasons favor the clinical and therapeutic application of adult stem cells over embryonic stem cells (ESCs), including controlled proliferation, exceptional reliability, and a site-specific differentiation ability [7]. Among adult stem cells, MSCs are frequently used to treat the most common cardiovascular diseases. MSCs can be found in the bone marrow (BM), adipose tissue, umbilical cord blood (UCB), and many other tissues. They have self-renewing properties and are multipotent progenitor cells that can differentiate into various lineages such as osteocytes, chondrocytes, adipocytes, and myocytes [8-11]. MSCs also have immunomodulatory properties $[12,13]$. In addition, MSCs are unlikely to lead to immune rejection because of their low expression of CD40, CD80, and CD86, as well as MHC class I molecules $[14,15]$. The therapeutic benefit of this approach is based on the potency of secretion of beneficial cytokines and growth factors for tissue repair/regeneration, as well as the immunomodulation effect and/or their differentiation for regenerating damaged organs [16].

MSCs can be applied for cardiovascular regeneration and provide therapeutic benefit for cardiovascular disease. However, MSCs have several disadvantages regarding their therapeutic application, including their very low survival rate in vivo and integration rate into the host cells after transplantation [17]. Another limitation is the low accuracy in delivering the stem cells to the damaged site [18]. Various attempts have been made to improve the poor survival and longevity of engrafted MSCs. The first step in developing therapeutic strategies is the identification of more effective reagents for promoting the ability of stem cells via understanding stem cell niche modulators. An emerging promising therapeutic strategy is the preconditioning of MSCs before transplantation using cytokines and natural compounds that induce intracellular signaling or niche stimulation through paracrine mechanisms [19]. Another is a tissue engineeringbased therapeutic strategy involving a cell scaffold, a cellprotein-scaffold architecture made of biomaterials such as ECM or hydrogel, and cell patch- and 3D printing-based tissue engineering, to enhance cell survival via cell-cell communication or cell-scaffold interactions [20].

This review focuses on promising cell therapeutic strategies for MSC therapy against cardiovascular diseases and introduces a variety of studies designed to promote the therapeutic efficacy of MSCs in vitro or in vivo from cell priming strategies to tissue engineering strategies for cardiovascular regeneration.

\section{Characterization of MSCs}

The term "mesenchymal stem cells" was introduced by Caplan in the early 1990s [21], although nonhematopoietic, "mesenchymal" precursor cells were first described in the 1970s by Friedenstein et al. as a population of bone marrow stromal cells capable of mesodermal differentiation and trophic support of hematopoiesis [22, 23].
MSCs are present in almost all tissues of the body and are located in the perivascular space [24]. They can also be isolated from other sources, such as adipose tissue [2530], cartilage [31, 32], umbilical cord blood [33-36], and peripheral blood [37]. In addition, MSCs can be derived from many different organs and tissues, including the brain, spleen, liver, kidney, lung, bone marrow, muscle, thymus, and pancreas [38].

The Mesenchymal and Tissue Stem Cell Committee of the International Society for Cellular Therapy (ISCT) set minimal criteria in 2001 for defining MSCs. They must be plastic-adherent when maintained in standard culture conditions. Second, MSCs must express CD105, CD73, and CD90 and lack the expression of CD45, CD34, CD14, or CD11b; CD79 $\alpha$ or CD19; and HLA-DR surface molecules as assessed by fluorescence-activated cell sorter analysis. Third, MSCs must be able to differentiate into osteoblasts, adipocytes and chondroblasts in vitro [39, 40]. Other surface markers generally expressed by MSCs include CD9, CD105 (SH2), CD73 (SH3/4), CD44, CD90 (Thy-1), CD71, CD106 (vascular cell adhesion molecule- [VCAM-] 1), CD166 (activated leukocyte cell adhesion molecule [ALCAM]), intercellular adhesion molecule- (ICAM-) 1, and CD29 [9, $14,41,42]$. Stem cells are characterized by their ability to self-renew, clone, and differentiate into multiple tissues [6]. MSCs are a pluripotent cell type that can differentiate into several distinct lineages, including mesodermal lineage cells (osteoblasts, chondrocytes, and adipocytes) $[9,43,44]$ and myogenic lineage [45]. Adipogenic differentiation is induced with FBS in medium supplemented with dexamethasone, insulin, isobutyl methyl xanthine, and indomethacin. The differentiation can be confirmed by the staining of lipid vacuoles with oil red $\mathrm{O}[46,47]$ and measuring the levels of several proteins, including PPAR $\gamma$, fatty acid-binding protein aP2, and lipoprotein lipase [27]. For osteogenic differentiation, MSCs are treated with ascorbic acid, beta-glycerophosphate, and dexamethasone. The differentiation is confirmed increase in alkaline phosphatase activity and calcium deposition [47, 48]. Chondrogenic differentiation is induced by culture with serum-free medium supplemented with transforming growth factor-beta (TGF- $\beta$ ), resulting in an increase in the levels of highly glycosaminoglycan and type II collagen $[46,49]$.

Recently, in vivo studies demonstrated that human MSCs transdifferentiate into endoderm-derived cells and cardiomyocytes [50-52], and MSCs transdifferentiated into a cardiomyocyte-phenotype [53]. Animal preclinical studies of MSC administration in post-MI hearts revealed the ability of MSCs to engraft, differentiate, and produce substantial functional recovery [54-57]. In recent years, MSCs therapy has been translated to clinical trials for ischemic heart disease [58-60].

\section{Clinical Trials Using MSCs against Cardiovascular Diseases}

Cell-based treatments represent a new generation in the evolution of biological therapeutics. A prototypic cell-based therapy for heart failure using MSCs has successfully reached 
the pivotal phase III trials, indicating adequate safety and efficacy data from phases I and II trials. Successful phase III trials can lead to the approval of a new biologic therapy for regenerative medicine [61]. There have been about 43 clinical trials using MSCs in relation to cardiovascular regeneration registered with clinicaltrials.gov (Table 1, a web-based service by the US National Institute of Health). Among the MSCbased clinical trials, studies designed to treat cardiovascular disease represent a substantial proportion (14.8\%) [62]. On the basis of the rigorous preclinical testing highlighted above that demonstrated the safety of MSC delivery to patients with cardiac disease, clinical trials have been initiated for both acute MI and ischemic cardiomyopathy. The results of a clinical trial of autologous MSC transplantation might aid in improving the long-term survival of patients with severe heart failure and significantly reduce hospitalizations for worsening angina [63]. A much smaller study revealed that both autologous BM MNCs and expanded BM MSCs reduced myocardial scarring by 3 months, indicating the stimulation of beneficial tissue remodeling [64]. The intracoronary administration of MSCs has been shown to have a minor benefit on the left ventricular ejection fraction [65], and a meta-analysis of cell therapies involving intracoronary administration found that there was no clinical benefit for left ventricular function [66]. The four clinical trials of plasmonic photothermal therapy (PPTT) using silicagold nanoparticles demonstrated the significant regression of coronary atherosclerosis [67]. In an early stage study of patients with ICM, the transendocardial injections of allogeneic and autologous MSCs without a placebo control were both associated with low rates of treatment-emergent SAEs, including immunologic reactions [68]. Transendocardial stem cell injection with MSCs or BMCs appeared to be safe for patients with chronic ischemic cardiomyopathy and LV dysfunction [69]. The intramyocardial injection of autologous MSCs into akinetic but nonrevascularized segments produced comprehensive regional functional restitution, which in turn drove improvement in global LV function. These findings, although inconclusive because of the lack of a placebo group, have important therapeutic and mechanistic hypothesis-generating implications [70].

\section{Understanding MSC Biology for Tissue Regeneration}

4.1. Enhancing MSC Survival for Cardiovascular Regeneration. In ischemic sites of ischemia-reperfusion injuries, cardiomyocytes undergo apoptosis [71]. Accumulating evidence clearly indicates that activated Akt signals protect cardiomyocytes from apoptosis. Similarly, transduced Akt in MSCs significantly enhanced their stem cell function in an in vivo rat model [72]. Lim et al. investigated the pivotal role of Akt-transduced MSCs in the ischemic porcine heart [55]. When applied to MI, Akt-MSCs administration increased the left ventricular ejection fraction and decreased the area of MI. Notably, Akt-MSCs have an enhanced cell survival ratio with augmented expression levels of ERK and VEGF, suggesting that administering Akt-transduced MSCs might be a promising therapeutic strategy for treating human patients with cardiovascular diseases.

Epidermal growth factor (EGF) is a well-known cytokine involved in cell growth and vascular tissue repair. In general, EGF binds to the EGF receptor (EGFR) and activates extracellular-regulated kinase (ERK) and Akt-mediated intracellular signaling pathways, resulting in increased cellular activities, including cell adhesion, migration, proliferation, and cell survival. Recently, it was reported that MSCs stimulated by soluble EGF induced EGFR signaling and promoted the upregulation of migration and proliferation [73]. Fan et al. also studied the pivotal role of surface-tethered EGF in MSC survival [74]. The proportion of total ERK that was phosphorylated was strongly linked to improved cell spreading and cell survival in tEGF-polymer conditions. Under these severe culture conditions, tEGF-polymer protected MSCs from FasL and eventually increased the survival rate, suggesting that tethered EGF might have protective functions in transplanted MSCs during acute inflammatory reactions.

Vascular endothelial growth factor (VEGF) has a pivotal role in cardiovascular regeneration. When MSCs isolated from B6 mice were cocultured with VEGF peptide, the primed MSCs exhibited reduced levels of cellular stress and higher expression of prosurvival factors via phosphorylation of Akt and Bcl-xL. The administration of MSCs primed with VEGF peptide in an MI disease model resulted in improved cardiac function via enhanced cell engraftment and cell survival capabilities, indicating that VEGF protects MSCs from cellular stress, leading to enhanced cardiac function and cardiovascular regeneration.

4.2. Enhancing MSC Proliferation for Cardiovascular Regeneration. In the human body, the subpopulations of MSCs are very small. Healthy MSCs dramatically activate their selfrenewal signaling pathway when required. After the onset of an injury caused by ischemic cardiovascular diseases, an insufficient MSC number leads to impaired tissue regeneration. Furthermore, the clinical use of MSCs for tissue regeneration has been limited mainly because they have a low proliferation rate and progressively lose their stem cell properties during in vitro expansion. To overcome these limitations, many research groups have studied the signaling cascades associated with MSC proliferation and identified pivotal modulators for MSC proliferation for use in the treatment of cardiovascular diseases [75].

Octamer-binding transcription factor 4 (Oct4) and sex determining region Y-box 2 (Sox2) are pluripotent stem cell-specific factors. The pivotal roles of these two factors in maintaining MSC stemness and proliferation have been studied $[76,77]$. Although early passage MSCs express Oct4 and Sox 2 at low levels, their expression levels decrease as the passage number increases. To improve MSC proliferation and stemness, human adipose tissue MSCs (ATMSCs) were transfected with Oct4 and Sox2 [78], and the MSCs that expressed Oct 4 and Sox 2 exhibited enhanced proliferative activity. This result was mediated by the upregulation of cyclin D1, indicating that the transition of cells from G1 to S phase might be accelerated. 
TABLE 1: Clinical trials with mesenchymal stem cells (https://clinicaltrials.gov/).

\begin{tabular}{|c|c|c|c|c|c|c|c|}
\hline & Study & $\begin{array}{c}\text { Year } \\
\text { (country) }\end{array}$ & Study status & Age & $\begin{array}{c}\text { Number } \\
\text { treated }\end{array}$ & Phase & Study ID \\
\hline 1 & Mesenchymal Stem Cells and Myocardial Ischemia & $\begin{array}{c}2010-2014 \\
\text { (France) }\end{array}$ & Completed & $\begin{array}{l}18 \text { years } \\
\text { and older }\end{array}$ & 10 & $\begin{array}{l}\text { Phase } 1 \\
\text { Phase } 2\end{array}$ & NCT01076920 \\
\hline 2 & $\begin{array}{l}\text { Administration of Mesenchymal Stem Cells in Patients } \\
\text { with Chronic Ischemic Cardiomyopathy (MESAMI2) }\end{array}$ & $\begin{array}{c}2015-2016 \\
\text { (France) }\end{array}$ & Ongoing & $\begin{array}{l}18 \text { years to } \\
75 \text { years }\end{array}$ & 90 & Phase 2 & NCT02462330 \\
\hline 3 & $\begin{array}{l}\text { Stem Cell Therapy for Vasculogenesis in Patients with } \\
\text { Severe Myocardial Ischemia }\end{array}$ & $\begin{array}{l}\text { 2009-2013 } \\
\text { (Denmark) }\end{array}$ & Completed & $\begin{array}{l}30 \text { years to } \\
80 \text { years }\end{array}$ & 31 & $\begin{array}{l}\text { Phase } 1 \\
\text { Phase } 2\end{array}$ & NCT00260338 \\
\hline 4 & $\begin{array}{c}\text { Human Umbilical-Cord-Derived Mesenchymal Stem } \\
\text { Cell Therapy in Ischemic Cardiomyopathy }\end{array}$ & $\begin{array}{c}\text { 2015-2018 } \\
\text { (China) }\end{array}$ & Ongoing & $\begin{array}{l}18 \text { years to } \\
80 \text { years }\end{array}$ & 40 & $\begin{array}{l}\text { Phase } 1 \\
\text { Phase } 2\end{array}$ & NCT02439541 \\
\hline 5 & $\begin{array}{l}\text { MesenchYmal STROMAL CELL Therapy in Patients with } \\
\text { Chronic Myocardial Ischemia (MyStromalCell Trial) }\end{array}$ & $\begin{array}{c}2010-2014 \\
\text { (Denmark) }\end{array}$ & Completed & $\begin{array}{l}30 \text { years to } \\
80 \text { years }\end{array}$ & 60 & Phase 2 & NCT01449032 \\
\hline 6 & $\begin{array}{l}\text { Safety and Exploratory Efficacy Study of UCMSCs in } \\
\text { Patients With Ischemic Heart Disease (SEESUPIHD) }\end{array}$ & $\begin{array}{c}2016-2017 \\
\text { (China) }\end{array}$ & Ongoing & $\begin{array}{l}18 \text { years to } \\
70 \text { years }\end{array}$ & 64 & $\begin{array}{l}\text { Phase } 1 \\
\text { Phase } 2\end{array}$ & NCT02666391 \\
\hline 7 & $\begin{array}{c}\text { Intracoronary Autologous Mesenchymal Stem Cells } \\
\text { Implantation in Patients with Ischemic Dilated } \\
\text { Cardiomyopathy }\end{array}$ & $\begin{array}{l}2012-2015 \\
\text { (Malaysia) }\end{array}$ & Ongoing & $\begin{array}{l}35 \text { years to } \\
75 \text { years }\end{array}$ & 80 & Phase 2 & NCT01720888 \\
\hline 8 & $\begin{array}{c}\text { Therapy of Preconditioned Autologous BMMSCs for } \\
\text { Patients With Ischemic Heart Disease }\end{array}$ & $\begin{array}{c}2015-2017 \\
\text { (China) }\end{array}$ & Ongoing & $\begin{array}{l}\text { up to } 75 \\
\text { years }\end{array}$ & 200 & $\begin{array}{l}\text { Phase } 1 \\
\text { Phase } 2 \\
\end{array}$ & NCT02504437 \\
\hline 9 & $\begin{array}{c}\text { The TRansendocardial Stem Cell Injection Delivery } \\
\text { Effects on Neomyogenesis STudy (The TRIDENT Study) }\end{array}$ & $\begin{array}{c}2013-2017 \\
\text { (USA) }\end{array}$ & Ongoing & $\begin{array}{l}21 \text { years to } \\
90 \text { years }\end{array}$ & 30 & Phase 2 & NCT02013674 \\
\hline 10 & $\begin{array}{l}\text { Mesenchymal Stem Cell Administration in the Treatment } \\
\text { of Coronary Graft Disease in Heart Transplant Patients }\end{array}$ & $\begin{array}{c}2014-2017 \\
\text { (France) }\end{array}$ & Ongoing & $\begin{array}{l}18 \text { years to } \\
80 \text { years }\end{array}$ & 14 & $\begin{array}{l}\text { Phase } 1 \\
\text { Phase } 2\end{array}$ & NCT02472002 \\
\hline 11 & $\begin{array}{c}\text { Safety and Efficacy of Intracoronary Adult Human } \\
\text { Mesenchymal Stem Cells after Acute Myocardial } \\
\text { Infarction }\end{array}$ & $\begin{array}{l}2007-2011 \\
\text { (Korea) }\end{array}$ & Completed & $\begin{array}{l}18 \text { years to } \\
70 \text { years }\end{array}$ & 80 & $\begin{array}{l}\text { Phase } 2 \\
\text { Phase } 3\end{array}$ & NCT01392105 \\
\hline 12 & $\begin{array}{l}\text { Human Umbilical Cord Stroma MSC in Myocardial } \\
\text { Infarction }\end{array}$ & $\begin{array}{l}2014-2017 \\
\text { (Turky) }\end{array}$ & Ongoing & $\begin{array}{c}30 \text { years to } \\
80 \text { years }\end{array}$ & 79 & $\begin{array}{l}\text { Phase } 1 \\
\text { Phase } 2\end{array}$ & NCT02323477 \\
\hline 13 & $\begin{array}{c}\text { Stem Cell Injection to Treat Heart Damage during Open } \\
\text { Heart Surgery }\end{array}$ & $\begin{array}{l}2012-2020 \\
\text { (USA) }\end{array}$ & Ongoing & $\begin{array}{l}18 \text { years to } \\
85 \text { years }\end{array}$ & 60 & Phase 1 & NCT01557543 \\
\hline 14 & $\begin{array}{c}\text { Safety Study of Adult Mesenchymal Stem Cells (MSC) to } \\
\text { Treat Acute Myocardial Infarction }\end{array}$ & $\begin{array}{l}2005-2014 \\
\text { (Australia) }\end{array}$ & Completed & $\begin{array}{l}21 \text { years to } \\
85 \text { years }\end{array}$ & 53 & Phase 1 & NCT00114452 \\
\hline 15 & $\begin{array}{c}\text { RELIEF (A Randomized, Open labEled, muLticenter } \\
\text { Trial for Safety and Efficacy of Intracoronary Adult } \\
\text { Human Mesenchymal stEm Cells Acute Myocardial } \\
\text { inFarction) }\end{array}$ & $\begin{array}{l}2012-2016 \\
\text { (Korea) }\end{array}$ & Ongoing & $\begin{array}{l}20 \text { years to } \\
70 \text { years }\end{array}$ & 135 & Phase 3 & NCT01652209 \\
\hline 16 & $\begin{array}{l}\text { Intracoronary Human Wharton's Jelly-Derived } \\
\text { Mesenchymal Stem Cells (WJ-MSCs) Transfer in } \\
\text { Patients with Acute Myocardial Infarction (AMI) }\end{array}$ & $\begin{array}{l}2011-2015 \\
\text { (China) }\end{array}$ & Completed & $\begin{array}{l}18 \text { years } \\
\text { and older }\end{array}$ & 160 & Phase 2 & NCT01291329 \\
\hline 17 & $\begin{array}{l}\text { Ex Vivo Cultured Bone Marrow Derived Allogenic MSCs } \\
\text { in AMI }\end{array}$ & $\begin{array}{c}2009-2013 \\
\text { (India) }\end{array}$ & Completed & $\begin{array}{l}20 \text { years to } \\
70 \text { years }\end{array}$ & 20 & $\begin{array}{l}\text { Phase } 1 \\
\text { Phase } 2\end{array}$ & NCT00883727 \\
\hline 18 & $\begin{array}{c}\text { "ESTIMATION Study" for Endocardial Mesenchymal } \\
\text { Stem Cells Implantation in Patients after Acute } \\
\text { Myocardial Infarction }\end{array}$ & $\begin{array}{l}2011-2016 \\
\text { (Russia) }\end{array}$ & Ongoing & $\begin{array}{l}30 \text { years to } \\
75 \text { years }\end{array}$ & 50 & Phase 3 & NCT01394432 \\
\hline 19 & $\begin{array}{l}\text { Prochymal }^{\circledR} \text { (Human Adult Stem Cells) Intravenous } \\
\text { Infusion following Acute Myocardial Infarction (AMI) }\end{array}$ & $\begin{array}{l}2009-2016 \\
\text { (Australia) }\end{array}$ & Ongoing & $\begin{array}{l}21 \text { years to } \\
85 \text { years }\end{array}$ & 220 & Phase 2 & NCT00877903 \\
\hline 20 & $\begin{array}{l}\text { Plasmonic Nanophotothermic Therapy of } \\
\text { Atherosclerosis }\end{array}$ & $\begin{array}{c}2007-2015 \\
\text { (Russia) }\end{array}$ & $\begin{array}{l}\text { Completed } \\
\text { Has results }\end{array}$ & $\begin{array}{l}45 \text { years to } \\
65 \text { years }\end{array}$ & 180 & $\begin{array}{l}\text { Phase } 1 \\
\text { Phase } 2\end{array}$ & NCT01270139 \\
\hline 21 & $\begin{array}{c}\text { The Percutaneous Stem Cell Injection Delivery Effects on } \\
\text { Neomyogenesis Pilot Study (The POSEIDON-Pilot } \\
\text { Study) }\end{array}$ & $\begin{array}{l}2010-2015 \\
\text { (USA) }\end{array}$ & $\begin{array}{l}\text { Completed } \\
\text { Has results }\end{array}$ & $\begin{array}{l}21 \text { years to } \\
90 \text { years }\end{array}$ & 31 & $\begin{array}{l}\text { Phase } 1 \\
\text { Phase } 2\end{array}$ & NCT01087996 \\
\hline 22 & $\begin{array}{c}\text { The Transendocardial Autologous Cells (hMSC or } \\
\text { hBMC) in Ischemic Heart Failure Trial (TAC-HFT) }\end{array}$ & $\begin{array}{c}2008-2015 \\
\text { (USA) }\end{array}$ & $\begin{array}{l}\text { Completed } \\
\text { Has results }\end{array}$ & $\begin{array}{l}21 \text { years to } \\
90 \text { years }\end{array}$ & 65 & $\begin{array}{l}\text { Phase } 1 \\
\text { Phase } 2\end{array}$ & NCT00768066 \\
\hline 23 & $\begin{array}{l}\text { Safety and Efficacy Study of Stem Cell Transplantation to } \\
\text { Treat Dilated Cardiomyopathy }\end{array}$ & $\begin{array}{l}2013-2015 \\
\text { (Slovenia, } \\
\text { USA) }\end{array}$ & Completed & $\begin{array}{l}18 \text { years to } \\
80 \text { years }\end{array}$ & 110 & Phase 2 & NCT00629018 \\
\hline
\end{tabular}


TABLE 1: Continued.

\begin{tabular}{|c|c|c|c|c|c|c|c|}
\hline & Study & $\begin{array}{c}\text { Year } \\
\text { (country) }\end{array}$ & Study status & Age & $\begin{array}{c}\text { Number } \\
\text { treated }\end{array}$ & Phase & Study ID \\
\hline 24 & $\begin{array}{c}\text { Prospective Randomized Study of Mesenchymal Stem } \\
\text { Cell Therapy in Patients Undergoing Cardiac Surgery } \\
\text { (PROMETHEUS) }\end{array}$ & $\begin{array}{l}2007-2015 \\
\text { (USA) }\end{array}$ & $\begin{array}{l}\text { Completed } \\
\text { Has results }\end{array}$ & $\begin{array}{l}21 \text { years to } \\
80 \text { years }\end{array}$ & 9 & $\begin{array}{l}\text { Phase } 1 \\
\text { Phase } 2\end{array}$ & NCT0 \\
\hline 25 & $\begin{array}{l}\text { Human Umbilical Cord-derived Mesenchymal Stem } \\
\text { Cells with Injectable Collagen Scaffold Transplantation } \\
\text { for Chronic Ischemic Cardiomyopathy }\end{array}$ & $\begin{array}{l}2015-2018 \\
\text { (China) }\end{array}$ & Ongoing & $\begin{array}{l}35 \text { years to } \\
65 \text { years }\end{array}$ & 45 & $\begin{array}{l}\text { Phase } 1 \\
\text { Phase } 2\end{array}$ & NCT02 \\
\hline 26 & $\begin{array}{l}\text { The Effect of Mobilized Stem Cell by G-CSF and VEGF } \\
\text { Gene Therapy in Patients with Stable Severe Angina } \\
\text { Pectoris }\end{array}$ & $\begin{array}{l}2003-2011 \\
\text { (Denmark) }\end{array}$ & Completed & $\begin{array}{l}20 \text { years to } \\
80 \text { years }\end{array}$ & 48 & $\begin{array}{l}\text { Phase } 1 \\
\text { Phase } 2\end{array}$ & NCTC \\
\hline 27 & $\begin{array}{l}\text { Plasmonic Photothermal and Stem Cell Therapy of } \\
\text { Atherosclerosis versus Stenting }\end{array}$ & $\begin{array}{c}2010-2015 \\
\text { (Russia) }\end{array}$ & Term & $\begin{array}{l}45 \text { years to } \\
65 \text { years }\end{array}$ & 62 & Phase 1 & NCT01436123 \\
\hline 28 & $\begin{array}{l}\text { Clinical Trial of Autologous Adipose Tissue Derived } \\
\text { Stromal Cell Therapy for Ischemic Heart Failure }\end{array}$ & $\begin{array}{c}\text { 2012-2014 } \\
\text { (Japan) }\end{array}$ & $\begin{array}{r}\text { En } \\
\text { in }\end{array}$ & $\begin{array}{l}20 \text { years } \\
\text { and older }\end{array}$ & 6 & - & NCT01709279 \\
\hline 29 & $\begin{array}{l}\text { Safety Study of Allogeneic Mesenchymal Precursor Cell } \\
\text { Infusion in MyoCardial Infarction }\end{array}$ & $\begin{array}{c}2012-2015 \\
\text { (USA) }\end{array}$ & Ongoing & $\begin{array}{l}18 \text { years } \\
\text { and older }\end{array}$ & 225 & Phase 2 & NCT01781390 \\
\hline 30 & $\begin{array}{c}\text { PercutaneOus StEm Cell Injection Delivery Effects On } \\
\text { Neomyogenesis in Dilated CardioMyopathy (The } \\
\text { POSEIDON-DCM Study) }\end{array}$ & $\begin{array}{c}\text { 2011-2016 } \\
\text { (USA) }\end{array}$ & Ongoing & $\begin{array}{c}18 \text { years to } \\
95 \text { years }\end{array}$ & 36 & $\begin{array}{l}\text { Phase } 1 \\
\text { Phase } 2\end{array}$ & NCT01392625 \\
\hline
\end{tabular}

The Wnt signaling pathway regulates cell proliferation and cell fate determination [79]. The canonical Wnt signaling pathway is a well-known Wnt signaling pathway involved in stem cell biology. Wnt ligands secreted from a cell can affect the cell itself (autocrine) or neighboring cells (paracrine), and they bind to their receptor, low-density lipoprotein receptor-related protein (LRP) 5/6. As a result, stabilized $\beta$ catenin is translocated to the nucleus, where it upregulates its downstream genes. Activation of the canonical Wnt signaling pathway in stem cells results in increased proliferation or selfrenewal activity in ESCs, neural stem cells (NSCs) [80], and HSCs [81]. In addition to previous studies on stem cells, MSC regulation by Wnt signaling pathways has been investigated. When adult MSCs are treated with Wnt3a ligand, a typical ligand for the canonical Wnt signaling pathway, the MSCs exhibit enhanced proliferation, but decreased apoptosis [82]. However, treatment with secreted frizzled-related protein 3, a canonical Wnt signaling inhibitor, had opposite effects on MSCs. Another research group used lithium as a proliferation activator [83] to target glycogen synthase kinase-3 $\beta$ (GSK$3 \beta$ ), a downstream protein in the canonical Wnt signaling pathway. When BM-derived MSCs were treated with lithium, the proportion of cells in $S$ phase and expression levels of cyclin D1 were significantly increased. In contrast, Wnt5a, a noncanonical Wnt member, has been reported to promote MSC differentiation [84, 85], suggesting that a distinct mechanism of Wnt ligand-mediated MSC signaling might be involved.

Estrogen is the primary female sex hormone and controls the female reproductive system and secondary sex characteristics, indicating its multifunctional roles in many tissues. Similar to many other types of cells, MSCs have estrogen receptor $(\alpha$ and $\beta$ ), suggesting that estrogen might affect MSC function. Estradiol (E2), a major form of estrogen, was found to affect MSC proliferation [86]. 17- $\beta$ estradiol-pretreated
MSCs exhibited a significantly increased proliferation rate in vitro, although it did not alter the MSC phenotypes, including the surface marker expression of MSCs such as CD105 and CD166. Based on these data, 17- $\beta$ estradiol might be a priming agent for enhancing MSC function in practical applications.

\subsection{Enhancing MSC Homing for Cardiovascular Regeneration.} The process of delivering cells to injured tissues is called "homing," which is induced in response to a diverse array of molecules including chemokines and growth factors. To overcome the insufficient number of homed MSCs, many researchers have investigated the pivotal regulators of MSC homing to ischemic sites.

MSCs strongly express CXC chemokine receptor 4 (CXCR4) on their surface. Stromal-derived factor-1 (SDF1), which is secreted from ischemic tissues, binds to CXCR4 on the MSC surface, inducing MSC migration to injured sites. In line with this mechanism, MSCs were retrovirally transduced with a CXCR4 overexpression vector and preclinically applied to an MI disease model [87]. As a result, there were an increased cell number of transplanted cells, and echocardiographic imaging of the MI area showed less anterior wall thinning and improvement in the left ventricular (LV) chamber dimensions.

Arachidonic acid (AA) is a polyunsaturated omega-6 fatty acid found in the cell's membrane, and it plays a critical role as a lipid second messenger. Although it has been reported that injured tissues release large amounts of AA, the detailed and precise mechanism is not fully understood. The effect of AA on skin wound healing was studied with human umbilical cord blood-derived MSCs (hUCB-MSCs) [88], and preconditiong hUCB-MSCs with AA improved wound healing, reepithelization, and angiogenesis. AA activates mammalian target of rapamycin complex 
2 (mTORC2) and Akt via the GPR40/phosphoinositide 3kinase (PI3K) signaling pathway. p38 is phosphorylated by PKCל and it activates Spl. As a result, membrane type 3matrix metalloproteinase (MT3-MMP) is stimulated, and eventually the secreted MT3-MMPs degrade fibronectin and facilitate hUCB-MSC migration, suggesting that skin wound healing might be promoted by priming MSCs with AA via MT3-MMP-dependent fibronectin degradation.

An effective cell therapy for MI requires accurate MSC delivery. To enhance MSC homing activity, phage display approaches have been used to screen MI-specific peptide sequences [89]. In a mouse MI model, four peptide sequences were identified, CRPPR, CRKDKC, KSTRKS, and CARSKNKDC, which are synthesized as palmitated derivatives. MI homing peptides-coated MSCs were injected into a mouse model of MI, and the number of migrated MSCs was greater in the coated groups than in the noncoated groups, indicating that the coating of MSCs with homing peptides is a promising therapeutic methodology for treating cardiovascular diseases including MI.

\section{Priming Strategies for Therapeutic MSCs for Cardiovascular Regeneration}

In general, the low survival rate of transplanted stem cells in ischemic myocardium has limited their therapeutic efficacy against ischemic cardiovascular diseases. Accumulating evidence indicates that the pharmacological pretreatment of MSCs ex vivo is a rational approach to reinforce the cells so that they can withstand the ischemic and reperfusion injury environment [90-92], although researchers first should define and clarify potential priming molecules and agents for cardiovascular regeneration.

Curcumin effectively protects MSCs from oxidative stress via regulation of PTEN/Akt/p53 and HO-1 signaling proteins and thereby promotes VEGF release from MSCs, facilitating the enhancement of cardiac function, improving cells retention, and reducing fibrosis in MI hearts [90]. As a conventional inductor, 5-azacytidine (5-AZA) has been used to induce MSC differentiation into cardiomyocytes [53, 93, 94]. Similarly, BMP-2 present in the embryonic heart was used to differentiate ESCs or induce pluripotent stem cells (iPS) into cardiomyocyte-like cells $[95,96]$, which opens up new possibilities for cardiomyocyte differentiation from MSCs [97].

Angiotensin-II (Ang-II) is peptide hormone that is produced from angiotensin-I (Ang-I) through modifications by angiotensin-converting enzyme (ACE). It is well-known that Ang-II increases blood volume and pressure. MSCs pretreated with Ang-II trigger VEGF production. Based on the effect of Ang-II on VEGF production, the therapeutic efficacy of Ang-II-preconditioned MSCs was investigated [98]. MSCs, isolated from Sprague-Dawley rats, were pretreated with $100 \mathrm{nM}$ of Ang-II for 24 hours and injected into the border zone of the ischemic heart. After 30 days, the restoration efficacy of MSCs was evaluated by measuring angiogenesis, cardiac function, cell differentiation fibrosis, infarct size, and VEGF expression. Ang-II-MSCs exhibited better cardiac function, higher expression of VEGF and von Willebrand factor (vWF), less cardiac fibrosis, and a smaller infarct size. In addition, preconditioning MSCs with Ang-II resulted in an increased survival rate and enhanced tube formation via the upregulation of connexin-43 (Cx43), suggesting that priming MSCs with Ang-II improved their therapeutic efficacy by enhancing angiogenesis and gap junction formation, in addition to the paracrine effect of VEGF against MI.

Fucoidan, a natural compound found in brown algae and seaweed, has various functional properties in biological processes. This sulfated polysaccharide reacts with cytokines and contributes to improving cell functional activity, including antioxidant effects, proliferation, and differentiation. The effects of fucoidan on preconditioned adipose tissue-derived MSCs (ADSCs) were evaluated in a chronic kidney disease (CKD) model [99]. Fucoidan-ADSCs exhibited increased proliferation potential with a significant increase in cell cycle-associated proteins such as cyclin E, cyclin D1, cyclin dependent kinase 2 (CDK 2), and CDK4. When applied to a CKD disease model, the in vivo transplantation of fucoidan-ADSCs enhanced the proliferation, incorporation, and endothelial differentiation of transplanted MSCs in ischemic sites, revealing a novel therapeutic strategy of using MSCs for cardiovascular regeneration.

\section{Tissue Engineering Strategies: A Powerful Application of MSC-Mediated
Vascular Regeneration}

Stem cells derived from healthy tissue can be used for tissue regeneration. In studies of cardiac tissue regeneration, researchers originally focused on organ transplantation. However, with the development of stem cell-based technics, stem cells are predicted to be useful for cardiac tissue regeneration. Particularly, MSCs are promising candidates for heart failure treatment because of their unique characteristics. Over the past decade, MSCs have gained attention as a therapeutic approach for treating MI compared with other cell types considered for cardiomyoplasty. MSCs have unique properties that may translate into convenient and extremely effective cell therapy $[8,100]$. Recent reports have questioned their "transdifferentiation" potential after injection into the myocardium and suggested the benefits of MSC mechanisms [101]. However, the tissues regenerated by this tissue engineering and widely applied to patients are still very limited, including skin, bone, cartilage, capillary, and periodontal tissues. What are the reasons for such slow advances in clinical applications of tissue engineering? This article gives the brief overview on the current tissue engineering, covering the fundamentals and applications.

6.1. Biomaterial-Based Tissue Engineering for Cardiovascular Regeneration. Biomaterials are biofriendly materials that have been engineered to interact with biological systems, and they are capable of protecting transplanted cells against harsh ischemic environments, including low oxygen, nutrient depletion, and severe attack by inflammatory cells [102].

Scaffolds containing silicon dioxide for tissue engineering enhance MSC growth through ERK1/2 activation [103]. 
Another study showed that the proliferation of hMSCs cultured in media containing 2 or $4 \mu \mathrm{M}$ silicon was significantly higher than that in control medium, suggesting the enhanced mechanical strength of the medium with silicon may have contribute to this result [104]. Other scaffolds, such as collagen-HA, also enhance MSC attachment and proliferation [105], and collagen I scaffolds exhibit excellent cellular compatibility [106]. Similarly, nanoparticle-containing liposomes were cultured with MSCs to make sheet-like structures [107]. The MSC sheets were layered on the ischemic tissues, and the recovery efficiency was evaluated. The organized structure of MSC sheets provided protection against ischemic limb diseases due to increased blood flow and recovery of angiogenesis, suggesting that tissue engineering scaffolds containing nanoparticles might improve MSC growth and that single-component silica-derived nanoparticles could be advantageous for scaffolds used in stem cell therapy $[103,108]$. In addition, various biomaterials have been employed in 3D scaffolds for cultured MSCs, such as chitosan, silk, and alginate [109-111].

Cell-based gene therapy combined with biomaterialbased tissue engineering offers an alternative strategy for therapeutic angiogenesis. Chinese hamster ovary $(\mathrm{CHO})$ cells were transfected with pCDNA3-VEGF-hemagglutinin (HA) vector [112]. The genetically modified $\mathrm{CHO}$ cells secreted VEGF and they were enveloped into semipermeable microcapsules. When the microencapsulated VEGF-CHO cells were transplanted into the MI region of rats, the capillary density of the microencapsulated VEGF-CHO cell group was significantly higher than that of the control group, with functional improvement of the injured heart. Wang et al. also examined the effect of the transplantation of microencapsulated Schwann cells with MSCs on angiogenesis [113]. In the harsh microenvironment of the nervous system, Schwann cells secrete VEGF, which enhances neuronal survival [114]. When semipermeable alginate-poly-L-lysine-alginate microcapsules containing Schwann cells and MSCs were applied to an acute myocardial infarction (AMI) rat model, they improved cardiac function because the recipient cells avoided the immune reaction due to the microencapsulation, and they secreted VEGF through small pores on their surface. Another research group investigated genetically modified MSCs that secreted glucagon-like peptide 1 (GLP-1) [115], which regulates blood glucose homeostasis and has a cardioprotective effect in heart disease. When Bead-GLP-1 MSCs were delivered to coronary artery branches in a porcine MI model, the echocardiography results showed improved left ventricular (LV) function, whereas histological analysis showed reduced inflammation and a lower apoptosis rate, indicating that combining the therapeutic strategies of utilizing recombinant GLP-1 and the inherent paracrine stem cell factors of MSCs might be beneficial for clinical application against MI.

Recently, cardiac patch-based therapeutics have been suggested as novel noninvasive methods functional strategies for cardiac regeneration because they can overcome the negative aspects of invasive surgery including complications resulting from the altered mechanics of the infarcted heart [116]. Bioengineered cardiac patches are made from a stem cell seeded multilayered scaffold. Briefly, stem cells, including MSCs, cardiac progenitor cells (CPCs), and endothelial progenitor cells (EPCs), grow on the cell-sheet culture system and generate a cell-sheet structure that can be cultured multiple times. Recently, MSC patches were applied to infarcted hearts with a previously described protocol [117]. The engineered MSC sheets represent a tightly adhered meshwork with adhesive agents, including fibronectin and laminin. MSC patches were attached to the ligated left coronary artery (LCA) in rats. Twelve weeks after patch implantation, echocardiography and heart catheterization were performed. The MSC patch implanted group exhibited improved heart function. In addition, neomuscle fibers and neomicrovessels were observed in the ligated LCA, as well as increased levels of angiogenic cytokines (bFGF, vWF, and PDGF-B) and cardioprotective factors (IGF-1 and HGF) in the MSC patch group, indicating the effectiveness of the bioengineered MSC patch as a therapeutic strategy against cardiovascular diseases including MI. (Figure 1). Taken together, studies of potential bioengineered cardiac patches-based therapeutics may improve the therapeutic efficacy of transplanted MSCs to overcome the limited number of multilayer of cardiac patches for cell survival and complications resulting from the altered mechanics of the infarcted heart and improve cell infiltration and migration of transplanted patch-derived MSCs.

6.2. Emerging 3D Printing-Based Tissue Engineering for Cardiovascular Regeneration. 3D printing is a novel manufacturing technique in which $3 \mathrm{D}$ objects can be synthesized. Objects that researchers want to make are captured with computed tomography (CT) or magnetic resonance imaging (MRI). Then, a 3D computer assisted design (CAD) model is developed from the captured objects. Digitally sliced images are generated by a visualized motion program. Finally, the captured objects are printed with a 3D printer, and they can be reprinted as needed [118]. Similar to commercial personal printers, 3D printers require ink. 3D printers, however, can use many types of ink. The human body is composed of various types of tissue. These tissue structures cover a wide range of sizes and stiffness. To meet these different demands, many types of ink have been developed. To develop functional 3Dengineered tissue constructs, various key components should be evaluated.

3D-engineered tissue constructs require several key components, such as cells, extracellular matrix (ECM), and vasculature. Each component supports a biomimetic function of the engineered tissue constructs. Thick vascularized tissues were made by bioprinting with 3D cell-laden ink [119] using two types of ink. Fugitive (vascular) ink contains pluronic and thrombin, and cell-laden ink contains gelatin, fibrinogen, thrombin, transglutaminase, and cells. Fugitive ink is printed on a 3D perfusion chip. Then, cell-laden ink is cast over the printed inks. Gelatin and fibrins are cross-linked by diffused transglutaminase from the molten casting matrix. Upon cooling, the fugitive ink liquefies and is evacuated, leaving behind a pervasive vascular network. hMSCs and human neonatal dermal fibroblasts (hNDFs) are subsequently lined with human umbilical vein endothelial cells (HUVECs). 


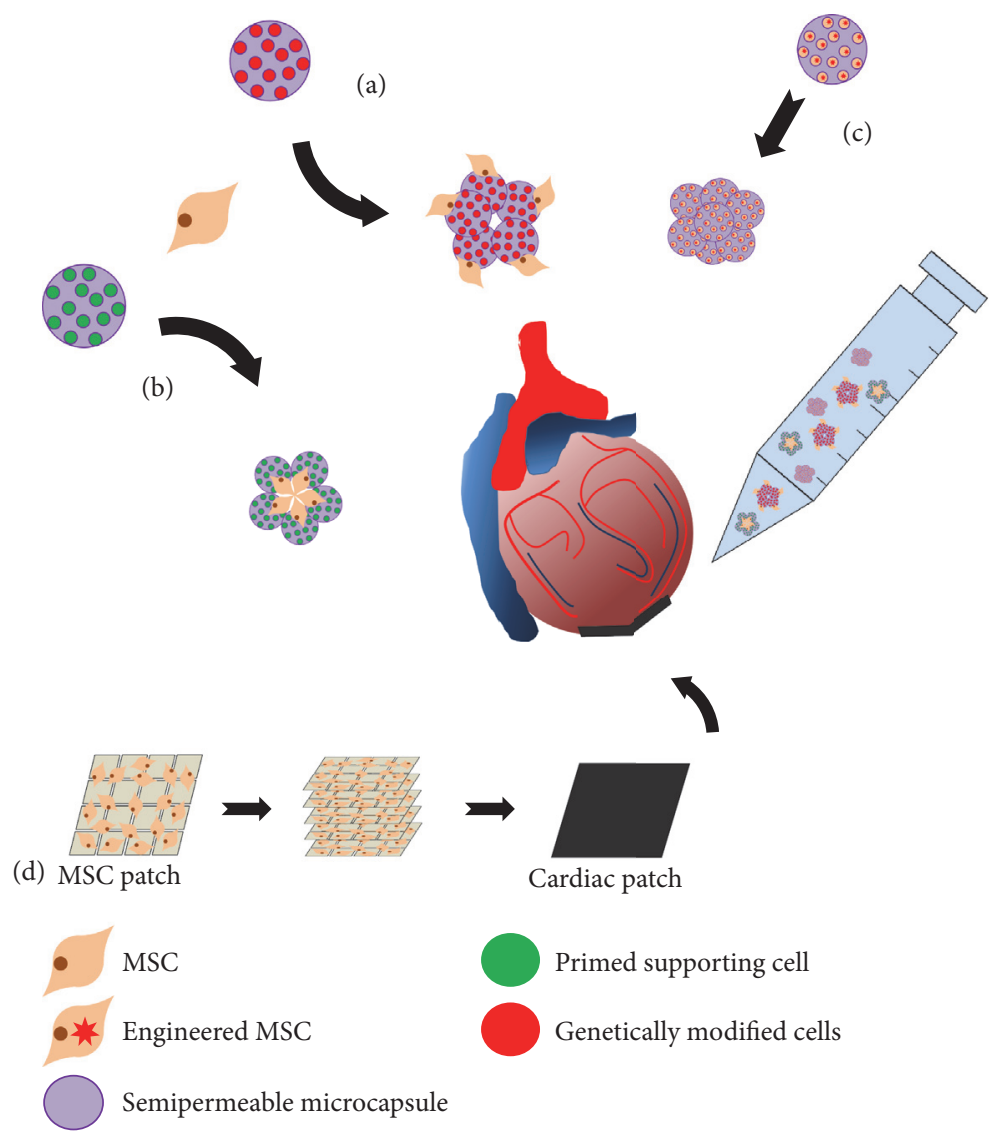

FIGURE 1: Therapeutic strategies of MSC-based tissue engineering. (a) Genetically modified MSCs are encapsulated into semipermeable microcapsules. This modified MSC secrete cytokine for homed stem cell. (b) Semipermeable microcapsules containing primed supporting cells. Secreted cytokines from primed supporting cells enhance MSC cellular function. (c) Engineered MSCs encapsulated into semipermeable microcapsules. MSCs secreted recombinant hormone such as glucagon-like peptide 1. Each semipermeable microcapsule is transplanted into infracted region of heart. (d) MSCs seeded on biomaterial-based patch. Multilayered cells as a cardiac patch for myocardial infraction.

These thick vascularized tissues are actively perfused with growth factors necessary for differentiation of hMSCs. Taken together, 3D printing has gained a considerable amount of attention owing to its ability to provide precise control of the initial structure of tissue-engineered constructs [102], indicating that 3D scaffold architecture and geometric cues play a major role in dictating cell behavior and tissue regeneration (Figure 2).

\section{Conclusion}

MSCs can be readily isolated from various sources in the human body. In addition, MSCs are able to self-replicate for many passages and differentiate into multiple cell lineages, such as osteoblasts, myoblasts, and fibroblasts. Thus, MSCs have become the most practical and prominent therapeutic stem cell. Recently, a number of research groups have focused on applying MSC-based therapies clinically relevant disease models. Based on MSC signaling pathways, natural compounds or chemical drugs are used to improve of MSC functions. Moreover, scientists are working to develop novel materials that are biologically inert. With the advances in technology, it is possible to modulate the microstructure of biomaterials to enable their practical use in medicine. An artificial structure composed of modified biomaterials can enhance MSC proliferation, survival, and differentiation. Tissue engineering technologies such as cell-scaffolds, cellprotein-scaffold architectures made of biomaterials including ECM or hydrogel, and cell patch- and 3D printing-based tissue techniques allow researchers to make artificial versions of human tissues and organs. Because of its numerous applications, a combined therapeutic strategy that includes cell priming and tissue engineering technology is a promising therapeutic approach for cardiovascular regeneration.

\section{Competing Interests}

The authors declare that they do not have any conflict of interests.

\section{Authors' Contributions}

Seung Taek Ji, Hyunyun Kim, and Jisoo Yun contributed equally to this study. 

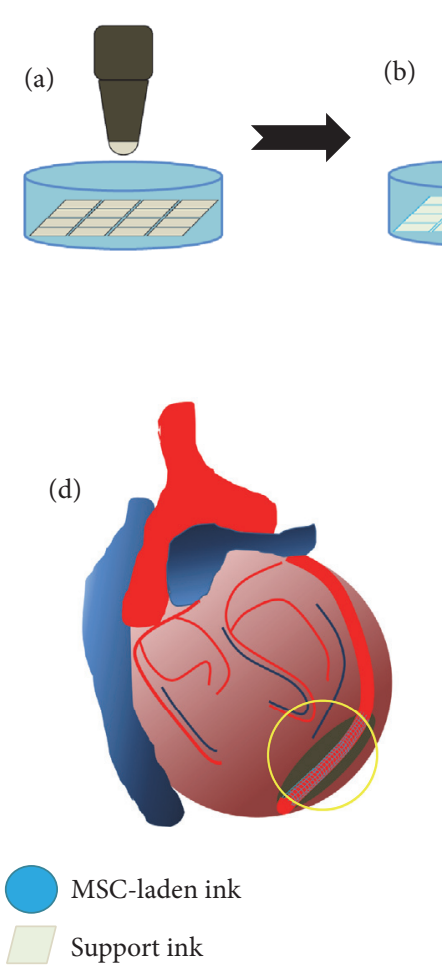

Support ink

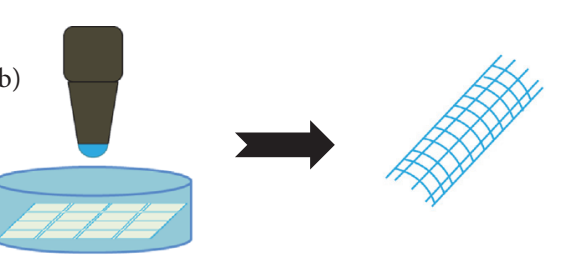

(c)

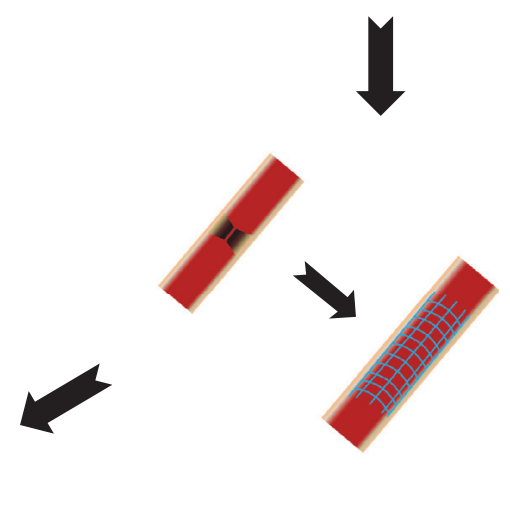

FIGURE 2: 3D printing-based tissue engineering for myocardiac infarction. (a) Casting a support frame with support ink. (b) MSC-laden ink is cast over the support ink. (c)-(d) 3D printing-based engineered tissues could be used for myocardiac infarction treatment.

\section{Acknowledgments}

This work was supported by a grant from the National Research Foundation (NRF-2015M3A9B4051053, NRF2015R1A5A2009656, NRF-2015M3A9B4066493, NRF2014R1A1 A2056907, and NRF-2015R1A2A2A01004908) and the Brain Busan 21 (BB21) program.

\section{References}

[1] GBD 2013 Mortality and Causes of Death Collaborators, "Global, regional, and national age-sex specific all-cause and cause-specific mortality for 240 cause of death, 1990-2013: a systematic analysis for the global burden of disease study 2013," The Lancet, vol. 385, no. 9963, pp. 117-171, 2015.

[2] A. E. Guttmacher, F. S. Collins, and E. G. Nabel, "Cardiovascular disease," New England Journal of Medicine, vol. 349, no. 1, pp. 60-72, 2003.

[3] C. Meads, C. Cummins, K. Jolly, A. Stevens, A. Burls, and C. Hyde, "Coronary artery stents in the treatment of ischaemic heart disease: a rapid and systematic review," Health Technology Assessment, vol. 4, no. 23, pp. 1-153, 2000.

[4] T. D. Henry, B. H. Annex, G. R. McKendall et al., "The VIVA trial: vascular endothelial growth factor in ischemia for vascular angiogenesis," Circulation, vol. 107, no. 10, pp. 1359-1365, 2003.

[5] A. Rozanski, J. A. Blumenthal, and J. Kaplan, "Impact of psychological factors on the pathogenesis of cardiovascular disease and implications for therapy," Circulation, vol. 99, no. 16, pp. 2192-2217, 1999.

[6] V. F. M. Segers and R. T. Lee, "Stem-cell therapy for cardiac disease," Nature, vol. 451, no. 7181, pp. 937-942, 2008.
[7] K. W. Liechty, T. C. MacKenzie, A. F. Shaaban et al., "Human mesenchymal stem cells engraft and demonstrate site-specific differentiation after in utero transplantation in sheep," Nature Medicine, vol. 6, no. 11, pp. 1282-1286, 2000.

[8] M. F. Pittenger and B. J. Martin, "Mesenchymal stem cells and their potential as cardiac therapeutics," Circulation Research, vol. 95, no. 1, pp. 9-20, 2004.

[9] M. F. Pittenger, A. M. Mackay, S. C. Beck et al., "Multilineage potential of adult human mesenchymal stem cells," Science, vol. 284, no. 5411, pp. 143-147, 1999.

[10] I. Ullah, R. B. Subbarao, and G. J. Rho, "Human mesenchymal stem cells-current trends and future prospective," Bioscience Reports, vol. 35, Article ID e00191, 2015.

[11] C. Nombela-Arrieta, J. Ritz, and L. E. Silberstein, "The elusive nature and function of mesenchymal stem cells," Nature Reviews Molecular Cell Biology, vol. 12, no. 2, pp. 126-131, 2011.

[12] R. Atoui and R. C. J. Chiu, "Mesenchymal stromal cells as universal donor cells," Expert Opinion on Biological Therapy, vol. 12, no. 10, pp. 1293-1297, 2012.

[13] W. Faiella and R. Atoui, "Therapeutic use of stem cells for cardiovascular disease," Clinical and Translational Medicine, vol. 5, no. 1, article 34, 2016.

[14] K. Le Blanc, C. Tammik, K. Rosendahl, E. Zetterberg, and O. Ringdén, "HLA expression and immunologic properties of differentiated and undifferentiated mesenchymal stem cells," Experimental Hematology, vol. 31, no. 10, pp. 890-896, 2003.

[15] J. Stagg, S. Pommey, N. Eliopoulos, and J. Galipeau, "Interferon$\gamma$-stimulated marrow stromal cells: a new type of nonhematopoietic antigen-presenting cell," Blood, vol. 107, no. 6, pp. 2570-2577, 2006. 
[16] D. M. Patel, J. Shah, and A. S. Srivastava, "Therapeutic potential of mesenchymal stem cells in regenerative medicine," Stem Cells International, vol. 2013, Article ID 496218, 15 pages, 2013.

[17] L. Li, X. Chen, W. E. Wang, and C. Zeng, "How to improve the survival of transplanted mesenchymal stem cell in ischemic heart?" Stem Cells International, vol. 2016, Article ID 9682757, 14 pages, 2016.

[18] J. M. Karp and G. S. L. Teo, "Mesenchymal stem cell homing: the devil is in the details," Cell Stem Cell, vol. 4, no. 3, pp. 206-216, 2009.

[19] P. R. Baraniak and T. C. McDevitt, "Stem cell paracrine actions and tissue regeneration," Regenerative Medicine, vol. 5, no. 1, pp. 121-143, 2010.

[20] N. Zippel, M. Schulze, and E. Tobiasch, "Biomaterials and mesenchymal stem cells for regenerative medicine," Recent patents on biotechnology, vol. 4, no. 1, pp. 1-22, 2010.

[21] A. I. Caplan, "Mesenchymal stem cells," Journal of Orthopaedic Research, vol. 9, no. 5, pp. 641-650, 1991.

[22] A. J. Friedenstein, R. K. Chailakhjan, and K. S. Lalykina, "The development of fibroblast colonies in monolayer cultures of guinea-pig bone marrow and spleen cells," Cell and Tissue Kinetics, vol. 3, no. 4, pp. 393-403, 1970.

[23] A. J. Friedenstein, U. F. Gorskaja, and N. N. Kulagina, "Fibroblast precursors in normal and irradiated mouse hematopoietic organs," Experimental Hematology, vol. 4, no. 5, pp. 267-274, 1976.

[24] R. Hass, C. Kasper, S. Böhm, and R. Jacobs, "Different populations and sources of human mesenchymal stem cells (MSC): a comparison of adult and neonatal tissue-derived MSC," Cell Communication and Signaling, vol. 9, article 12, 2011.

[25] A. P. Franco Lambert, A. Fraga Zandonai, D. Bonatto, D. Cantarelli Machado, and J. A. Pêgas Henriques, "Differentiation of human adipose-derived adult stem cells into neuronal tissue: does it work?" Differentiation, vol. 77, no. 3, pp. 221-228, 2009.

[26] S. Gronthos, D. M. Franklin, H. A. Leddy, P. G. Robey, R. W. Storms, and J. M. Gimble, "Surface protein characterization of human adipose tissue-derived stromal cells," Journal of Cellular Physiology, vol. 189, no. 1, pp. 54-63, 2001.

[27] A.-M. Rodriguez, C. Elabd, E.-Z. Amri, G. Ailhaud, and C. Dani, "The human adipose tissue is a source of multipotent stem cells," Biochimie, vol. 87, no. 1, pp. 125-128, 2005.

[28] B. Lindroos, S. Boucher, L. Chase et al., "Serum-free, xeno-free culture media maintain the proliferation rate and multipotentiality of adipose stem cells in vitro," Cytotherapy, vol. 11, no. 7, pp. 958-972, 2009.

[29] S. Schreml, P. Babilas, S. Fruth et al., "Harvesting human adipose tissue-derived adult stem cells: resection versus liposuction," Cytotherapy, vol. 11, no. 7, pp. 947-957, 2009.

[30] L. Sensebé and P. Bourin, "Mesenchymal stem cells for therapeutic purposes," Transplantation, vol. 87, no. 9S, pp. S49-53, 2009.

[31] S. Alsalameh, R. Amin, T. Gemba, and M. Lotz, "Identification of mesenchymal progenitor cells in normal and osteoarthritic human articular cartilage," Arthritis and Rheumatism, vol. 50, no. 5, pp. 1522-1532, 2004.

[32] K. Hiraoka, S. Grogan, T. Olee, and M. Lotz, "Mesenchymal progenitor cells in adult human articular cartilage," Biorheology, vol. 43, no. 3-4, pp. 447-454, 2006.

[33] M. Secco, Y. B. Moreira, E. Zucconi et al., "Gene expression profile of mesenchymal stem cells from paired umbilical cord units: cord is different from blood," Stem Cell Reviews and Reports, vol. 5, no. 4, pp. 387-401, 2009.
[34] M. Jäger, C. Zilkens, B. Bittersohl, and R. Krauspe, "Cord blood-an alternative source for bone regeneration," Stem Cell Reviews and Reports, vol. 5, no. 3, pp. 266-277, 2009.

[35] K. Bieback and H. Klüter, "Mesenchymal stromal cells from umbilical cord blood," Current Stem Cell Research and Therapy, vol. 2, no. 4, pp. 310-323, 2007.

[36] C. Campagnoli, I. A. G. Roberts, S. Kumar, P. R. Bennett, I. Bellantuono, and N. M. Fisk, "Identification of mesenchymal stem/progenitor cells in human first-trimester fetal blood, liver, and bone marrow," Blood, vol. 98, no. 8, pp. 2396-2402, 2001.

[37] N. J. Zvaifler, L. Marinova-Mutafchieva, G. Adams et al., "Mesenchymal precursor cells in the blood of normal individuals," Arthritis Research, vol. 2, no. 6, pp. 477-488, 2000.

[38] L. da Silva Meirelles, P. C. Chagastelles, and N. B. Nardi, "Mesenchymal stem cells reside in virtually all post-natal organs and tissues," Journal of Cell Science, vol. 119, no. 11, pp. 22042213, 2006.

[39] M. Dominici, K. Le Blanc, I. Mueller et al., "Minimal criteria for defining multipotent mesenchymal stromal cells. The International Society for Cellular Therapy position statement," Cytotherapy, vol. 8, no. 4, pp. 315-317, 2006.

[40] E. M. Horwitz, K. Le Blanc, M. Dominici et al., "Clarification of the nomenclature for MSC: the International Society for Cellular Therapy position statement," Cytotherapy, vol. 7, no. 5, pp. 393-395, 2005.

[41] S. E. Haynesworth, M. A. Barer, and A. I. Caplan, "Cell surface antigens on human marrow-derived mesenchymal cells are detected by monoclonal antibodies," Bone, vol. 13, no. 1, pp. 6980, 1992.

[42] P. A. Conget and J. J. Minguell, "Phenotypical and functional properties of human bone marrow mesenchymal progenitor cells," Journal of Cellular Physiology, vol. 181, no. 1, pp. 67-73, 1999.

[43] J.-H. Hong, E. S. Hwang, M. T. McManus et al., "TAZ, a transcriptional modulator of mesenchymal stem cell differentiation," Science, vol. 309, no. 5737, pp. 1074-1078, 2005.

[44] A. I. Caplan and S. P. Bruder, "Mesenchymal stem cells: building blocks for molecular medicine in the 21st century," Trends in Molecular Medicine, vol. 7, no. 6, pp. 259-264, 2001.

[45] B. Short, N. Brouard, T. Occhiodoro-Scott, A. Ramakrishnan, and P. J. Simmons, "Mesenchymal stem cells," Archives of Medical Research, vol. 34, no. 6, pp. 565-571, 2003.

[46] A. Augello and C. De Bari, "The regulation of differentiation in mesenchymal stem cells," Human Gene Therapy, vol. 21, no. 10, pp. 1226-1238, 2010.

[47] H. Song, W. Chang, B. W. Song, and K. C. Hwang, "Specific differentiation of mesenchymal stem cells by small molecules," American Journal of Stem Cells, vol. 1, no. 1, pp. 22-30, 2012.

[48] I. Mahjneh, M.-R. Passos-Bueno, M. Zatz et al., "The phenotype of chromosome 2p-linked limb-girdle muscular dystrophy," Neuromuscular Disorders, vol. 6, no. 6, pp. 483-490, 1996.

[49] A. M. Mackay, S. C. Beck, J. M. Murphy, F. P. Barry, C. O. Chichester, and M. F. Pittenger, "Chondrogenic differentiation of cultured human mesenchymal stem cells from marrow," Tissue Engineering, vol. 4, no. 4, pp. 415-428, 1998.

[50] Y. Sato, H. Araki, J. Kato et al., "Human mesenchymal stem cells xenografted directly to rat liver are differentiated into human hepatocytes without fusion," Blood, vol. 106, no. 2, pp. 756-763, 2005. 
[51] C. Toma, M. F. Pittenger, K. S. Cahill, B. J. Byrne, and P. D. Kessler, "Human mesenchymal stem cells differentiate to a cardiomyocyte phenotype in the adult murine heart," Circulation, vol. 105, no. 1, pp. 93-98, 2002.

[52] A. R. Williams and J. M. Hare, "Mesenchymal stem cells: biology, pathophysiology, translational findings, and therapeutic implications for cardiac disease," Circulation Research, vol. 109, no. 8, pp. 923-940, 2011.

[53] W. Xu, X. Zhang, H. Qian et al., "Mesenchymal stem cells from adult human bone marrow differentiate into a cardiomyocyte phenotype in vitro," Experimental Biology and Medicine, vol. 229, no. 7, pp. 623-631, 2004.

[54] Y. S. Kim, J. S. Kwon, M. H. Hong et al., "Promigratory activity of oxytocin on umbilical cord blood-derived mesenchymal stem cells," Artificial Organs, vol. 34, no. 6, pp. 453-461, 2010.

[55] S. Y. Lim, Y. S. Kim, Y. Ahn et al., "The effects of mesenchymal stem cells transduced with Akt in a porcine myocardial infarction model," Cardiovascular Research, vol. 70, no. 3, pp. 530-542, 2006.

[56] H. C. Quevedo, K. E. Hatzistergos, B. N. Oskouei et al., "Allogeneic mesenchymal stem cells restore cardiac function in chronic ischemic cardiomyopathy via trilineage differentiating capacity," Proceedings of the National Academy of Sciences of the United States of America, vol. 106, no. 33, pp. 14022-14027, 2009.

[57] D. Wang, F. Zhang, W. Shen et al., "Mesenchymal stem cell injection ameliorates the inducibility of ventricular arrhythmias after myocardial infarction in rats," International Journal of Cardiology, vol. 152, no. 3, pp. 314-320, 2011.

[58] J. M. Hare, J. H. Traverse, T. D. Henry et al., "A randomized, double-blind, placebo-controlled, dose-escalation study of intravenous adult human mesenchymal stem cells (prochymal) after acute myocardial infarction," Journal of the American College of Cardiology, vol. 54, no. 24, pp. 2277-2286, 2009.

[59] B. Trachtenberg, D. L. Velazquez, A. R. Williams et al., "Rationale and design of the transendocardial injection of autologous human cells (bone marrow or mesenchymal) in chronic ischemic left ventricular dysfunction and heart failure secondary to myocardial infarction (TAC-HFT) trial: a randomized, double-blind, placebo-controlled study of safety and efficacy," American Heart Journal, vol. 161, no. 3, pp. 487-493, 2011.

[60] J. M. Hare, "Translational development of mesenchymal stem cell therapy for cardiovascular diseases," Texas Heart Institute Journal, vol. 36, no. 2, pp. 145-147, 2009.

[61] C. Sanina and J. M. Hare, "Mesenchymal stem cells as a biological drug for heart disease: where are we with cardiac cellbased therapy?" Circulation Research, vol. 117, no. 3, pp. 229-233, 2015.

[62] T. Squillaro, G. Peluso, and U. Galderisi, "Clinical trials with mesenchymal stem cells: an update," Cell Transplantation, vol. 25, no. 5, pp. 829-848, 2016.

[63] A. B. Mathiasen, M. Haack-Sørensen, E. Jørgensen, and J. Kastrup, "Autotransplantation of mesenchymal stromal cells from bone-marrow to heart in patients with severe stable coronary artery disease and refractory angina-final 3-year follow-up," International Journal of Cardiology, vol. 170, no. 2, pp. 246-251, 2013.

[64] A. R. Williams, B. Trachtenberg, D. L. Velazquez et al., "Intramyocardial stem cell injection in patients with ischemic cardiomyopathy: functional recovery and reverse remodeling," Circulation Research, vol. 108, no. 7, pp. 792-796, 2011.
[65] J.-W. Lee, S.-H. Lee, Y.-J. Youn et al., "A randomized, openlabel, multicenter trial for the safety and efficacy of adult mesenchymal stem cells after acute myocardial infarction," Journal of Korean Medical Science, vol. 29, no. 1, pp. 23-31, 2014.

[66] M. Gyöngyösi, W. Wojakowski, P. Lemarchand et al., "Metaanalysis of cell-based CaRdiac stUdiEs (ACCRUE) in patients with acute myocardial infarction based on individual patient data," Circulation Research, vol. 116, no. 8, pp. 1346-1360, 2015.

[67] A. N. Kharlamov, A. E. Tyurnina, V. S. Veselova, O. P. Kovtun, V. Y. Shur, and J. L. Gabinsky, "Silica-gold nanoparticles for atheroprotective management of plaques: results of the NANOM-FIM trial," Nanoscale, vol. 7, no. 17, pp. 8003-8015, 2015.

[68] J. M. Hare, J. E. Fishman, G. Gerstenblith et al., "Comparison of allogeneic vs autologous bone marrow-derived mesenchymal stem cells delivered by transendocardial injection in patients with ischemic cardiomyopathy: the POSEIDON randomized trial," The Journal of the American Medical Association, vol. 308, no. 22, pp. 2369-2379, 2012.

[69] A. W. Heldman, D. L. DiFede, J. E. Fishman et al., "Transendocardial mesenchymal stem cells and mononuclear bone marrow cells for ischemic cardiomyopathy: the TAC-HFT randomized trial," JAMA, vol. 311, no. 1, pp. 62-73, 2014.

[70] V. Karantalis, D. L. Difede, G. Gerstenblith et al., "Autologous mesenchymal stem cells produce concordant improvements in regional function, tissue perfusion, and fibrotic burden when administered to patients undergoing coronary artery bypass grafting: the Prospective Randomized Study of Mesenchymal Stem Cell Therapy in Patients Undergoing Cardiac Surgery (PROMETHEUS) trial," Circulation Research, vol. 114, no. 8, pp. 1302-1310, 2014.

[71] T. Matsui, J. Tao, F. Del Monte et al., "Akt activation preserves cardiac function and prevents injury after transient cardiac ischemia in vivo," Circulation, vol. 104, no. 3, pp. 330-335, 2001.

[72] A. A. Mangi, N. Noiseux, D. Kong et al., "Mesenchymal stem cells modified with Akt prevent remodeling and restore performance of infarcted hearts," Nature Medicine, vol. 9, no. 9, pp. 1195-1201, 2003.

[73] K. Tamama, V. H. Fan, L. G. Griffith, H. C. Blair, and A. Wells, "Epidermal growth factor as a candidate for ex vivo expansion of bone marrow-derived mesenchymal stem cells," Stem Cells, vol. 24, no. 3, pp. 686-695, 2006.

[74] V. H. Fan, A. Au, K. Tamama et al., “Tethered epidermal growth factor provides a survival advantage to mesenchymal stem cells," Stem Cells, vol. 25, no. 5, pp. 1241-1251, 2007.

[75] H. L. Michalis Mastri and T. Lee, "Enhancing the efficacy of mesenchymal stem cell therapy," World Journal of Stem Cells, vol. 6, no. 2, pp. 82-93, 2014.

[76] D. S. Yoon, Y. H. Kim, H. S. Jung, S. Paik, and J. W. Lee, "Importance of Sox2 in maintenance of cell proliferation and multipotency of mesenchymal stem cells in low-density culture," Cell Proliferation, vol. 44, no. 5, pp. 428-440, 2011.

[77] T. M. Liu, Y. N. Wu, X. M. Guo, J. H. P. Hui, E. H. Lee, and B. Lim, "Effects of ectopic nanog and Oct4 overexpression on mesenchymal stem cells," Stem Cells and Development, vol. 18, no. 7, pp. 1013-1022, 2009.

[78] S.-M. Han, S.-H. Han, Y.-R. Coh et al., "Enhanced proliferation and differentiation of Oct4- And Sox2-overexpressing human adipose tissue mesenchymal stem cells," Experimental and Molecular Medicine, vol. 46, no. 6, article no. e101, 2014.

[79] Y. Komiya and R. Habas, "Wnt signal transduction pathways," Organogenesis, vol. 4, no. 2, pp. 68-75, 2008. 
[80] R. Nusse, "Wnt signaling and stem cell control," Cell Research, vol. 18, no. 5, pp. 523-527, 2008.

[81] F. J. T. Staal and T. C. Luis, "Wnt signaling in hematopoiesis: crucial factors for self-renewal, proliferation, and cell fate decisions," Journal of Cellular Biochemistry, vol. 109, no. 5, pp. 844-849, 2010.

[82] G. M. Boland, G. Perkins, D. J. Hall, and R. S. Tuan, "Wnt 3a promotes proliferation and suppresses osteogenic differentiation of adult human mesenchymal stem cells," Journal of Cellular Biochemistry, vol. 93, no. 6, pp. 1210-1230, 2004.

[83] Z. Zhu, J. Yin, J. Guan et al., "Lithium stimulates human bone marrow derived mesenchymal stem cell proliferation through GSK-3 $\beta$-dependent $\beta$-catenin/Wnt pathway activation," FEBS Journal, vol. 281, no. 23, pp. 5371-5389, 2014.

[84] S. Guan, Z. Wang, F. Xin, and H. Xin, "Wnt5a is associated with the differentiation of bone marrow mesenchymal stem cells in vascular calcification by connecting with different receptors," Molecular Medicine Reports, vol. 10, no. 4, pp. 1985-1991, 2014.

[85] R. Bilkovski, D. M. Schulte, F. Oberhauser et al., "Role of Wnt$5 \mathrm{a}$ in the determination of human mesenchymal stem cells into preadipocytes," The Journal of Biological Chemistry, vol. 285, no. 9, pp. 6170-6178, 2010.

[86] L. Hong, G. Zhang, H. Sultana, Y. Yu, and Z. Wei, “The effects of $17-\beta$ estradiol on enhancing proliferation of human bone marrow mesenchymal stromal cells in vitro," Stem Cells and Development, vol. 20, no. 5, pp. 925-931, 2011.

[87] Z. Cheng, L. Ou, X. Zhou et al., "Targeted migration of mesenchymal stem cells modified with CXCR4 gene to infarcted myocardium improves cardiac performance," Molecular Therapy, vol. 16, no. 3, pp. 571-579, 2008.

[88] S. Y. Oh, S.-J. Lee, Y. H. Jung, H. J. Lee, and H. J. Han, "Arachidonic acid promotes skin wound healing through induction of human MSC migration by MT3-MMP-mediated fibronectin degradation," Cell Death and Disease, vol. 6, no. 5, 2015.

[89] T. J. Kean, L. Duesler, R. G. Young et al., "Development of a peptide-targeted, myocardial ischemia-homing, mesenchymal stem cell," Journal of Drug Targeting, vol. 20, no. 1, pp. 23-32, 2012.

[90] J. Liu, P. Zhu, P. Song et al., "Pretreatment of adipose derived stem cells with curcumin facilitates myocardial recovery via antiapoptosis and angiogenesis," Stem Cells International, vol. 2015, Article ID 638153, 12 pages, 2015.

[91] X.-B. Liu, H. Chen, H.-Q. Chen et al., "Angiopoietin-1 preconditioning enhances survival and functional recovery of mesenchymal stem cell transplantation," Journal of Zhejiang University: Science B, vol. 13, no. 8, pp. 616-623, 2012.

[92] H. K. Haider and M. Ashraf, "Preconditioning and stem cell survival," Journal of Cardiovascular Translational Research, vol. 3, no. 2, pp. 89-102, 2010.

[93] B. Balana, C. Nicoletti, I. Zahanich et al., "5-Azacytidine induces changes in electrophysiological properties of human mesenchymal stem cells," Cell Research, vol. 16, no. 12, pp. 949960, 2006.

[94] Y. Liu, J. Song, W. Liu, Y. Wan, X. Chen, and C. Hu, "Growth and differentiation of rat bone marrow stromal cells: does 5-azacytidine trigger their cardiomyogenic differentiation?" Cardiovascular Research, vol. 58, no. 2, pp. 460-468, 2003.

[95] H. Gai, E. L.-H. Leung, P. D. Costantino et al., "Generation and characterization of functional cardiomyocytes using induced pluripotent stem cells derived from human fibroblasts," Cell Biology International, vol. 33, no. 11, pp. 1184-1193, 2009.
[96] Z. Bin, L.-G. Sheng, Z.-C. Gang et al., "Efficient cardiomyocyte differentiation of embryonic stem cells by bone morphogenetic protein-2 combined with visceral endoderm-like cells," Cell Biology International, vol. 30, no. 10, pp. 769-776, 2006.

[97] J. Hou, A.-L. Lü, B.-W. Liu et al., "Combination of BMP-2 and 5AZA is advantageous in rat bone marrow-derived mesenchymal stem cells differentiation into cardiomyocytes," Cell Biology International, vol. 37, no. 12, pp. 1291-1299, 2013.

[98] C. Liu, Y. Fan, L. Zhou et al., "Pretreatment of mesenchymal stem cells with angiotensin II enhances paracrine effects, angiogenesis, gap junction formation and therapeutic efficacy for myocardial infarction," International Journal of Cardiology, vol. 188, no. 1, pp. 22-32, 2015.

[99] J. H. Lee, J. M. Ryu, Y.-S. Han et al., "Fucoidan improves bioactivity and vasculogenic potential of mesenchymal stem cells in murine hind limb ischemia associated with chronic kidney disease," Journal of Molecular and Cellular Cardiology, vol. 97, pp. 169-179, 2016.

[100] M. T. Elnakish, F. Hassan, D. Dakhlallah, C. B. Marsh, I. A. Alhaider, and M. Khan, "Mesenchymal stem cells for cardiac regeneration: translation to bedside reality," Stem Cells International, vol. 2012, Article ID 646038, 14 pages, 2012.

[101] M. Breitbach, T. Bostani, W. Roell et al., "Potential risks of bone marrow cell transplantation into infarcted hearts," Blood, vol. 110, no. 4, pp. 1362-1369, 2007.

[102] J. C. Bernhard and G. Vunjak-Novakovic, "Should we use cells, biomaterials, or tissue engineering for cartilage regeneration?" Stem Cell Research and Therapy, vol. 7, no. 1, article 56, 2016.

[103] K. J. Kim, Y. A. Joe, M. K. Kim et al., "Silica nanoparticles increase human adipose tissue-derived stem cell proliferation through ERK1/2 activation," International Journal of Nanomedicine, vol. 10, pp. 2261-2272, 2015.

[104] K. J. Kim, Y.-J. Jeon, J. H. Lee, and J.-W. Rhie, “The effect of silicon ion on proliferation and osteogenic differentiation of human ADSCs," Korean Tissue Engineering and Regenerative Medicine Society, vol. 7, no. 2, pp. 171-177, 2010.

[105] L. Ning, H. Malmström, and Y.-F. Ren, "Porous collagenHydroxyapatite scaffolds with mesenchymal stem cells for bone regeneration," Journal of Oral Implantology, vol. 41, no. 1, pp. 4549, 2015.

[106] Y.-S. Zhang, J.-H. Gao, F. Lu, M. Zhu, and Y.-J. Liao, “Cellular compatibility of type collagen I scaffold and human adiposederived stem cells," Nan Fang Yi Ke Da Xue Xue Bao, vol. 27, no. 2, pp. 223-225, 2007.

[107] M. Ishii, R. Shibata, Y. Numaguchi et al., "Enhanced angiogenesis by transplantation of mesenchymal stem cell sheet created by a novel magnetic tissue engineering method," Arteriosclerosis, Thrombosis, and Vascular Biology, vol. 31, no. 10, pp. 2210-2215, 2011.

[108] I.-S. Yoon, C. W. Chung, J.-H. Sung et al., "Proliferation and chondrogenic differentiation of human adipose-derived mesenchymal stem cells in porous hyaluronic acid scaffold," Journal of Bioscience and Bioengineering, vol. 112, no. 4, pp. 402408, 2011.

[109] R. Yao, R. Zhang, J. Luan, and F. Lin, "Alginate and alginate/gelatin microspheres for human adipose-derived stem cell encapsulation and differentiation," Biofabrication, vol. 4, no. 2, Article ID 025007, 2012.

[110] N.-C. Cheng, S. Wang, and T.-H. Young, "The influence of spheroid formation of human adipose-derived stem cells on chitosan films on stemness and differentiation capabilities," Biomaterials, vol. 33, no. 6, pp. 1748-1758, 2012. 
[111] J. R. Mauney, T. Nguyen, K. Gillen, C. Kirker-Head, J. M. Gimble, and D. L. Kaplan, "Engineering adipose-like tissue in vitro and in vivo utilizing human bone marrow and adiposederived mesenchymal stem cells with silk fibroin 3D scaffolds," Biomaterials, vol. 28, no. 35, pp. 5280-5290, 2007.

[112] H. Zhang, S.-J. Zhu, W. Wang, Y.-J. Wei, and S.-S. Hu, "Transplantation of microencapsulated genetically modified xenogeneic cells augments angiogenesis and improves heart function," Gene Therapy, vol. 15, no. 1, pp. 40-48, 2008.

[113] Y. Wang, G. Zhang, Y. Hou et al., "Transplantation of microencapsulated Schwann cells and mesenchymal stem cells augment angiogenesis and improve heart function," Molecular and Cellular Biochemistry, vol. 366, no. 1-2, pp. 139-147, 2012.

[114] J. M. Rosenstein, J. M. Krum, and C. Ruhrberg, "VEGF in the nervous system," Organogenesis, vol. 6, no. 2, pp. 107-114, 2010.

[115] J. H. Houtgraaf, R. de Jong, K. Monkhorst et al., "Feasibility of intracoronary GLP-1 eluting cellbead ${ }^{\mathrm{TM}}$ infusion in acute myocardial infarction," Cell Transplantation, vol. 22, no. 3, pp. 535-543, 2013.

[116] M. F. Berry and J. Friedberg, "Chest wall/diaphragmatic complications," Thoracic Surgery Clinics, vol. 16, no. 3, pp. 277-285, 2006.

[117] H.-J. Wei, C.-H. Chen, W.-Y. Lee et al., "Bioengineered cardiac patch constructed from multilayered mesenchymal stem cells for myocardial repair," Biomaterials, vol. 29, no. 26, pp. 35473556, 2008.

[118] H.-W. Kang, S. J. Lee, I. K. Ko, C. Kengla, J. J. Yoo, and A. Atala, "A 3D bioprinting system to produce human-scale tissue constructs with structural integrity," Nature Biotechnology, vol. 34, no. 3, pp. 312-319, 2016.

[119] D. B. Kolesky, K. A. Homan, M. A. Skylar-Scott, and J. A. Lewis, "Three-dimensional bioprinting of thick vascularized tissues," Proceedings of the National Academy of Sciences of the United States of America, vol. 113, no. 12, pp. 3179-3184, 2016. 

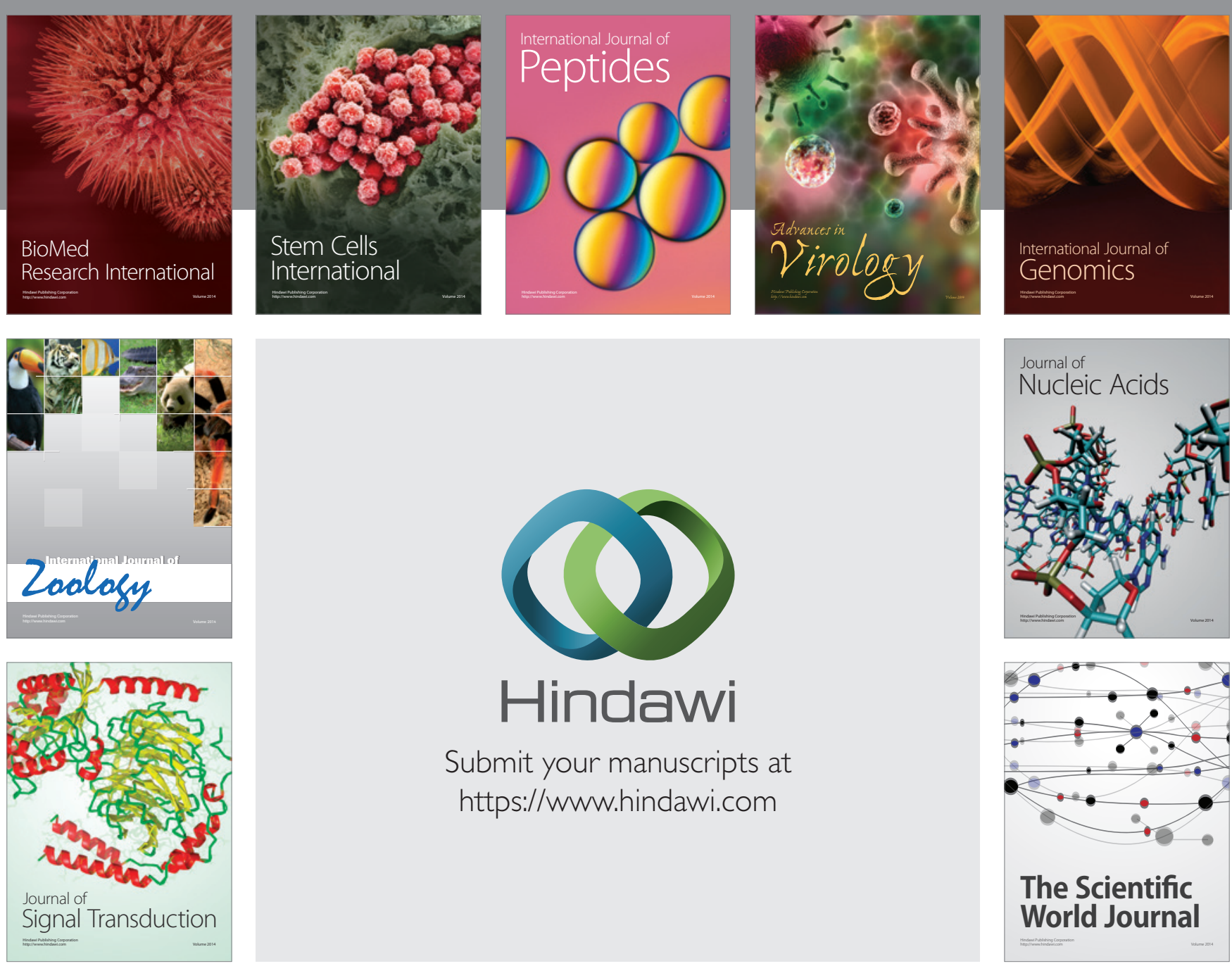

Submit your manuscripts at

https://www.hindawi.com
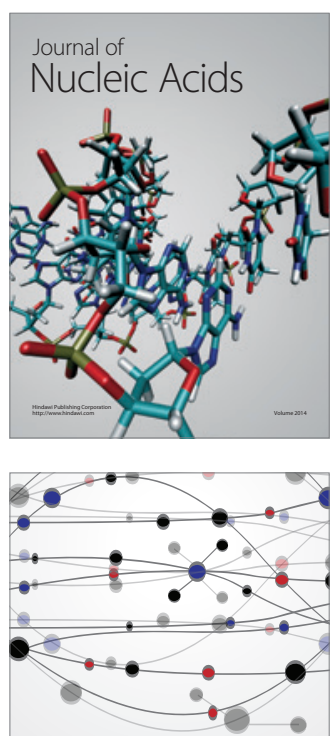

The Scientific World Journal
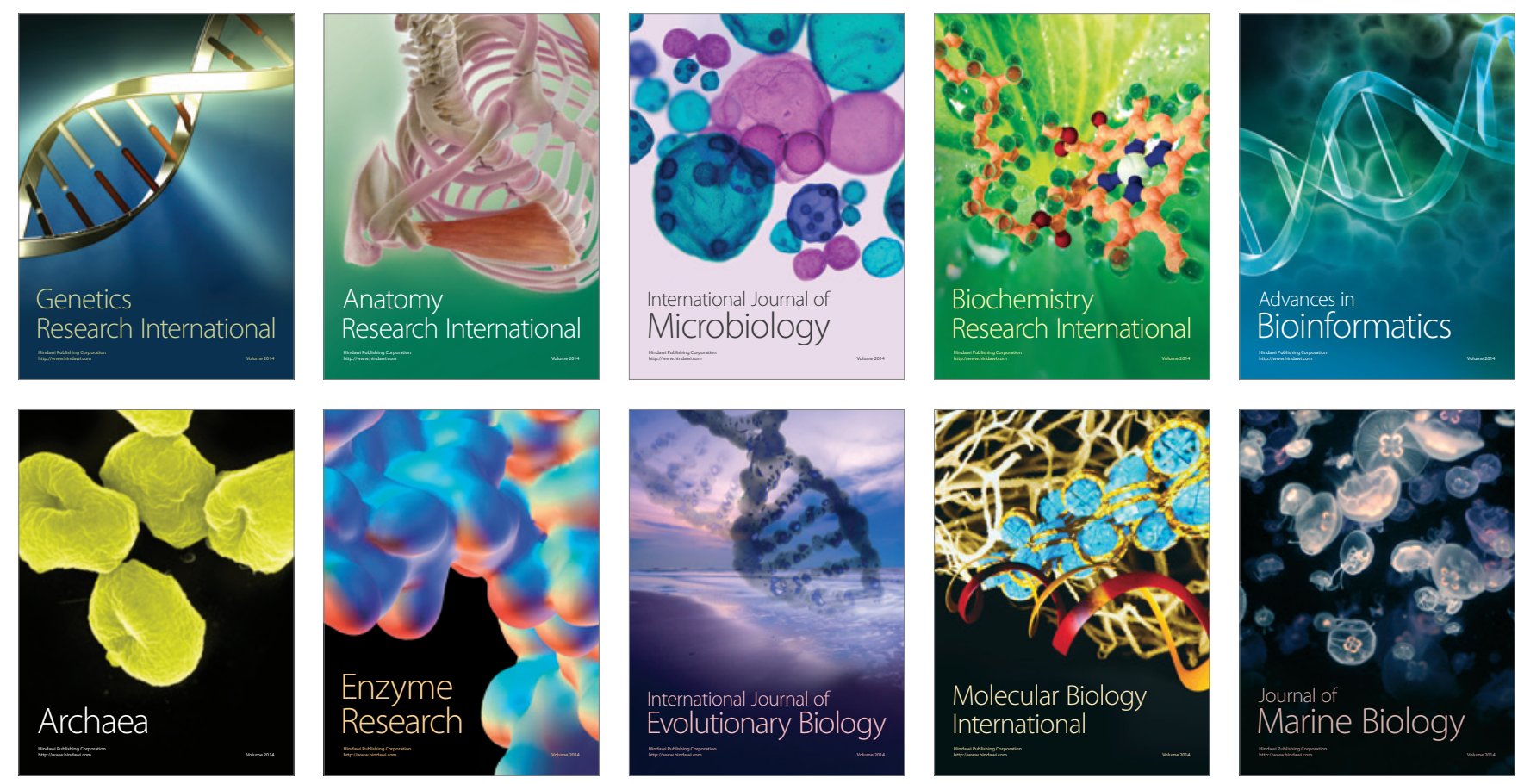